\title{
Pendidikan Sejarah Sebagai Penguat Pendidikan Karakter
}

\author{
Rulianto ${ }^{1 *}$, Febri Hartono ${ }^{1}$
}

${ }^{1}$ Program Studi Sejarah, FKIP, Universitas Mahasaraswat, Denpasar

Article history:

Received 31 Oktober 2018

Accepted 30 November

2018

Desember 2018

Kata Kunci:

Pendidikan Sejarah;

Pendidikan Karakter

Keywords:

History education;

Character education

\section{A R T I C L E I N F O}

Available online 31

\begin{abstract}
A B S T R A K
Pendidikan tidak hanya diartikan sebagai transfer pengetahuan melainkan transfer nilai, terutama nilai nilai yang terkandung dalam 18 nilai karakter yang ditargetkan dalam pendidikan karakter. Pendidikan adalah upaya untuk membentuk karakter siswa sehingga mereka dapat mengetahui dan membedakan antara yang baik dan buruk dalam kehidupan bermasyarakat, berbangsa dan bernegara. Pendidikan karakter saat ini sangat diperlukan untuk mengatasi masalah generasi penerus bangsa ini yang semakin sulit dikendalikan. Pembelajaran sejarah sebagai pendukung pendidikan karakter memiliki peran yang sangat sentral karena pembelajaran sejarah memiliki lingkup materi sebagai berikut: (1) mengandung nilai-nilai heroik, teladan, perintis, patriotisme, nasionalisme, dan semangat pantang menyerah yang mendasari proses pembentukan karakter dan kepribadian siswa; (2) berisi repertoar peradaban bangsa
\end{abstract} termasuk peradaban Indonesia; (3) menanamkan kesadaran persatuan dan persaudaraan dan solidaritas untuk menjadi bangsa yang bersatu dalam menghadapi ancaman disintegrasi; (4) mengandung ajaran dan kebijaksanaan moral yang berguna dalam mengatasi krisis multidimensi yang dihadapi dalam kehidupan sehari-hari; (5) menanamkan dan mengembangkan sikap tanggung jawab dalam menjaga keseimbangan lingkungan dan keberlanjutan. Dilihat dari ruang lingkup, sangat tepat jika pembelajaran sejarah digunakan untuk mendukung pendidikan karakter.

\section{A B S T R A C T}

Education is not only interpreted as the transfer of knowledge but rather the transfer of values, especially the value of values contained in 18 character values that are targeted in character education. Education is an effort to shape the character of students so that they can know and distinguish between the good and bad in the life of society, nation and state. Character education is currently very much needed to overcome the problems of the next generation of this nation which is increasingly difficult to control. History learning as a supporter of character education has a very central role because history learning has the following material scope: (1) contains heroic values, exemplary, pioneering, patriotism, nationalism, and unyielding spirit that underlies the process of character formation and personality of students; (2) contains repertoire of civilizations of nations including Indonesian civilization; (3) instill awareness of unity and brotherhood and solidarity to become a unifying nation in the face of threats of disintegration; (4) contains moral teachings and wisdom that are useful in overcoming the multidimensional crisis faced in daily life; (5) instill and develop an attitude of responsibility in maintaining environmental balance and sustainability. Judging from the scope, it is very appropriate if history learning is used to support the character education.

\footnotetext{
Corresponding author.

E-mail addresses: rulianto@unmas.ac.id
} 


\section{Pendahuluan}

Pendidikan merupakan sebuah lembaga sosial yang memiliki kewajiban untuk mempersiapkan sumber daya manusia yang unggul dan dapat bersaing dengan manusia lainnya. Selain membuat manusia unggul dalam akademik, pendidikan juga harus mampu membentuk watak dan kepribadian yang luhur, sehingga setelah seseorang mendapatkan pendidikan, akan memiliki kemampuan akademik serta dapat hidup dan berkembang baik dalam masyarakat, serta dapat memilah milah antara yang baik dan yang benar. Hal ini selaras dengan pendapat Zamroni (dalam Elmubarok, 2009:3) : Pendidikan adalah suatu proses menanamkan dan mengembangkan pada diri peserta didik pengetahuan tentang hidup, sikap dalam hidup agar kelak ia dapat membedakan barang yang benar dan yang salah, yang baik dan yang buruk, sehingga kehidupannya di tengah tengah masyarakat akan bermakna dan berfungsi secara optimal.

Berdasarkan pendapat di atas dapat di simpulkan bahwa, pendidikan merupakan usaha untuk membentuk karakter peserta didik agar mereka dapat mengetahui dan membedakan antara baik buruknya dalam kehidupan masyarakat, bangsa dan negara, sehingga pendidikan pada intinya sebagai penolong di tengah tengah kehidupan manusia.

Pendidikan haruslah mengarah pada tujuan pendidikan itu sendiri, agar tercapai keinginan bersama untuk menjadikan pendidikan yang lebih baik. Tujuan pendidikan Nasional kita yang berasal dari berbagai akar budaya bangsa Indonesia terdapat dalam Undang Undang sistem pendidikan Nasional. Dalam Undang Undang SISDIKNAS No.20 tahun 2003 tersebut, dikatakan: "pendidikan Nasional bertujuan untuk berkembangnya potensi peserta didik agar menjadi manusia yang beriman dan bertakwa kepada Tuhan yang Maha Esa, berakhlak mulia, sehat, berilmu, cakap, kreatif, mandiri, dan menjadi warga Negara yang demokratis,serta bertanggung jawab." Dengan dasar tujuan nasional yang telah disuratkan dalam Undang Undang SISDIKNAS No.20 tahun 2003 itu, setiap unit atau organisasi yang bergerak dalam bidang pendidikan dalam menjabarkan kegiatannya mengacu pada tujuan pendidikan nasional. Tujuan pendidikan nasional ditentukan oleh pemerintah bersama dewan perwakilan rakyat dengan memperhatikan masukan dari masyarakat atau para pakar yang berkompeten dan kemudian dirumuskan oleh pemerintah dan anggota DPR hasil rumusan tujuan pendidikan nasional tersebut tertuang dalam Undang Undang SISDIKNAS No.20 tahun 2003.

Pendidikan sejarah pada dasarnya adalah penanaman rasa waktu (time sense), yang tanpanya orang akan kehilangan orientasi temporal, I Gde Wijaya (dalam Susanto, 2014:42). "Mempelajari sejarah adalah mempelajari bagaimana menghargai waktu, menghargai peristiwa-peristiwa yang telah terjadi dan dijadikan sebagai pembelajaran untuk kehidupan yang di jalani saat ini dan yang akan datang".

Pembelajaran sejarah haruslah selalu berpatokan pada tujuan pembelajaran sejarah itu sendiri agar dalam pembelajaran sejarah tepat pada sasarannya. Menurut Moh. Ali ( dalam Susanto,2014:57) pembelajaran sejarah nasional memiliki tujuan yaitu : (1) Membangkitkan, mengembangkan memelihara semangat kebangsaan; (2) Membangkitkan hasrat mewujudkan cita-cita kebangsaan dalam segala lapangan; (3) Membangkitkan hasrat mempelajari sejarah kebangsaan dan mempelajarinya sebagai bagian dari sejarah Dunia; dan (4) Menyadarkan anak tentang cita-cita nasional (Pancasila dan Undang Undang pendidikan) serta perjuangan tersebut untuk mewujudkan cita-cita itu sepanjang masa.

Berdasarkan uraian di atas dapat di simpulkan bahwa pembelajaran sejarah nasional memfokuskan diri pada peserta didik agar tertanam nilai nilai karakter yang kuat, mampu mewujudkan cita-cita nasional serta membangkitkan hasrat untuk memiliki kesadaran dan kepedulian terhadap sejarah, memiliki semangat untuk meningkatkan kesadaran akan pentingnya kebudayaan serta menanamkan semangat untuk mempelajari sejarah, dan semangat kebangsaan terhadap tanah air, bangsa dan negaranya. Pedoman tujuan pembelajaran sejarah inilah yang harus di tanamkan oleh pendidik pendidik sejarah kepada peserta didik agar mereka senantiasa memandang sejarah itu teramat sangat penting untuk dipelajari sekaligus sebagai pendukung terwujudnya pendidikan karakter.

Permasalahan di dalam pengajaran sejarah, sebagian tenaga pendidik sejarah hanya terfokus pada hafalan dan menerapkan metode ceramah saja, sehingga peserta didik mengalami 
kejenuhan dalam pembelajaran sejarah dan memandang sejarah itu pelajaran yang sangat membosankan. Sebagian peserta didik juga memandang bahwa pelajaran sejarah sebagai pelajaran yang tidak bermanfaat dalam dunia nyata dan tidak ada kaitannya dengan dunia kerja. Ditambah lagi dengan lemahnya kemampuan pendidik sejarah dalam menjelaskan materi dan menciptakan lingkungan pembelajaran yang menarik bagi peserta didik. Kondisi pembelajaran sejarah yang seperti inilah yang tidak sesuai dengan tujuan pembelajaran sejarah Nasional.

Pendidik sejarah seharusnya senantiasa memperlakukan peserta didik sebagai subjek yang harus belajar dan mengembangkan diri, oleh karena itu proses belajar mengajar haruslah berorientasi pada kebutuhan dan kemampuan peserta didik, dan kegiatan kegiatan dalam proses pembelajaran pun harus senantiasa diarahkan untuk memberikan pengalaman belajar yang menyenangkan dan berguna bagi peserta didik. Trianto, (2008:4) menyatakan bahwa pembelajaran yang baik seharusnya dapat membantu peserta didik untuk memahami materimateri ajar dan mengaplikasikannya dalam kehidupan. Dalam pembelajaran sejarah guru seharusnya juga dapat mengaitkan materi materi sejarah dengan kehidupan nyata peserta didik di lingkungan mereka masing-masing, agar materi yang di ajarkan guru itu dirasa bermanfaat bagi peserta didik itu sendiri.

Seiring dengan kemajuan zaman dan perkembangan teknologi yang semakin maju, guru haruslah aktif untuk mengembangkan diri dan menemukan sesuatu yang baru untuk memajukan dunia pendidikan. Pendidik sejarah idealnya harus belajar, kreatif untuk mengembangkan diri, serta terus menerus menyesuaikan pengetahuan dan cara mengajar mereka dengan penemuan baru dalam dunia pendidikan, beragam unsur dan kendala dalam pendidikan dapat di antisipasi, Ukim (2013:2).

Pemaparan di atas semakin menegaskan bahwa pendidik sejarah harus mampu merancang strategi pembelajaran yang efektif agar siswa memperoleh pengalaman belajar yang menyenangkan dan berguna bagi dirinya. Selain itu, pendidik sejarah haruslah memiliki pengetahuan yang luas dan pemahaman yang mendalam. Di samping penguasaan materi, pendidik sejarah juga dituntut memiliki keragaman metode dan model pembelajaran, karena tidak ada satu metode atau model pembelajaran yang dapat digunakan untuk mencapai tujuan pembelajaran yang beragam. Apabila konsep pembelajaran ini dipahami oleh setiap guru, maka upaya mendesain pembelajaran bukan menjadi beban, tapi menjadi pekerjaan yang menantang. Dalam merancang strategi pembelajaran yang efektif dan berguna bagi peserta didik, pendidik sejarah juga harus mengerti tentang media pembelajaran sebagai alat untuk menunjang penyampaian materi agar lebih menarik dan mudah untuk diterima peserta didik. Satu hal lagi yang perlu di kembangkan adalah bagaimana guru dapat memunculkan kecakapan peserta didik yang aktif, inovatif dan kreatif.

\section{Hasil dan pembahasan}

1. Pendidikan Karakter

karakter adalah sifat-sifat kejiwaan, akhlak atau budi pekerti yang membedakan seseorang dengan yang lain. Pendidikan karakter adalah suatu sistem penanaman nilai-nilai karakter kepada siswa atau warga sekolah yang meliputi komponen pengetahuan, kesadaran atau kemauan, dan tindakan untuk melaksanakan nilai-nilai tersebut (Harsojo, 2013: 21). Pendidikan karakter menjadi gerakan nasional dalam sekolah sebagai agen untuk membangun karakter peserta didik melalui pembelajaran agar supaya tujuan dari proses pembelajaran tersebut mengarah kapada terbentuknya prilaku prilaku dalam kesehariannya sebagai pribadi yang santun, jujur, memiliki rasa ingin tahu yang tinggi terhadap pendidikan juga toleran.

Pendidikan karakter merupakan proses untuk menuntun peserta didik menjadi manusia seutuhnya yang berkarakter dalam hati, raga, pikir, serta rasa dan karsa. Pendidikan karakter dapat dimaknai sebagai pendidikan nilai, pendidikan budi pekerti, pendidikan moral, pendidikan watak, yang bertujuan mengembangkan kemampuan peserta didik untuk memberikan keputusan baik buruk, memelihara apa yang baik, dan mewujudkan kebaikan itu dalam kehidupan sehari-hari dengan sepenuh hati (Samani, 2011:45).

Selain itu terdapat delapan belas nilai-nilai dalam pendidikan karakter menurut Diknas adalah (Fathurrohman, 2013: 19): yaitu : 
1) Religius

Sikap dan perilaku yang patuh dalam melaksanakan ajaran agama yang dianutnya, toleran terhadap pelaksanaan ibadah agama lain, dan hidup rukun dengan pemeluk agama lain.

2) Jujur Perilaku yang didasarkan pada upaya menjadikan dirinya sebagai orang yang selalu dapat dipercaya dalam perkataan, tindakan, dan pekerjaan.

3) Toleransi Sikap dan tindakan yang menghargai perbedaan agama, suku, etnis, pendapat, sikap, dan tindakan orang lain yang berbeda dari dirinya.

4) Disiplin Tindakan yang menunjukkan perilaku tertib dan patuh pada berbagai ketentuan dan peraturan.

5) Kerja Keras Tindakan yang menunjukkan perilaku tertib dan patuh pada berbagai ketentuan dan peraturan.

6) Kreatif

Berpikir dan melakukan sesuatu untuk menghasilkan cara atau hasil baru dari sesuatu yang telah dimiliki.

7) Mandiri

Sikap dan perilaku yang tidak mudah tergantung pada orang lain dalam menyelesaikan tugas-tugas.

8) Demokratis

Cara berfikir, bersikap, dan bertindak yang menilai sama hak dan kewajiban dirinya dan orang lain.

9) Rasa Ingin Tahu

Sikap dan tindakan yang selalu berupaya untuk mengetahui lebih mendalam dan meluas dari sesuatu yang dipelajarinya, dilihat, dan didengar.

10) Semangat Kebangsaan

Cara berpikir, bertindak, dan berwawasan yang menempatkan kepentingan bangsa dan negara di atas kepentingan diri dan kelompoknya.

11) Cinta Tanah Air

Cara Berpikir, bertindak, dan berwawasan yang menempatkan kepentingan bangsa dan negara di atas kepentingan diri dan kelompoknya.

12) Menghargai Prestasi

Sikap dan tindakan yang mendorong dirinya untuk menghasilkan sesuatu yang berguna bagi masyarakat, dan mengakui, serta menghormati keberhasilan orang lain.

13) Bersahabat/Komunikatif

Sikap dan tindakan yang mendorong dirinya untuk menghasilkan sesuatu yang berguna bagi masyarakat, dan mengakui, serta menghormati keberhasilan orang lain.

14) Cinta Damai

Sikap dan tindakan yang mendorong dirinya untuk menghasilkan sesuatu yang berguna bagi masyarakat, dan mengakui, serta menghormati keberhasilan orang lain.

15) Gemar Membaca

Kebiasaan menyediakan waktu untuk membaca berbagai bacaan yang memberikan kebajikan bagi dirinya.

16) Peduli Lingkungan

Sikap dan tindakan yang selalu berupaya mencegah kerusakan pada lingkungan alam di sekitarnya, dan mengembangkan upaya-upaya untuk memperbaiki kerusakan alam yang sudah terjadi.

17) Peduli Sosial

Sikap dan tindakan yang selalu ingin memberi bantuan pada orang lain dan masyarakat yang membutuhkan.

18) Tanggung Jawab 
Sikap dan perilaku seseorang untuk melaksanakan tugas dan kewajibannya, yang seharusnya dia lakukan, terhadap diri sendiri, masyarakat, lingkungan (alam, sosial dan budaya), negara dan Tuhan Yang Maha Esa.

\section{Pendidikan Sejarah}

Pendidikan sejarah merupakan pendidikan yang sangat penting untuk mengajarkan kepada peserta didik akan pentingnya sejarah sebagai pembentuk kepribadian siswa. Sartono Kartodirdjo dalam (Susanto, 2014:35) berpendapat bahwa dalam rangka pembangunan bangsa, pengajaran sejarah tidak semata mata berfungsi untuk memberikan pengetahuan sejarah sebagai kumpulan informasi fakta sejarah tetapi juga bertujuan menyadarkan anak didik atau membangkitkan kemampuan berpikir kesejarahannya.

Pendidikan sejarah merupakan Pendidikan yang sanggat penting Untuk membentuk peserta didik memiliki pemikiran tentang sejarah yang tinggi, maka dalam pendidikan sejarah harus mengarah pada empat tujuan pendidikan sejarah itu sendiri. Menurut Hamid Hasan, dalam (Susanto, 2014;35), menyatakan bahwa, (1) pendidikan sejarah memberikan materi pendidikan yang mendasar, mendalam dan berdasarkan pengalaman bangsa di masa lalu untuk membangun kesadaran dan pemahaman tentang diri dan bangsanya. (2) Materi pendidikan sejarah merupakan materi pendidikan yang khas dalam membangun kemampuan berpikir logis, kritis, analisis, dan kreatif yang sesuai dengan tantangan kehidupan yang dihadapi pada masanya. (3) Pendidikan sejarah menyajikan materi dan contoh keteladanan, kepemimpinan, kepeloporan, sikap dan tindakan manusia dalam kelompoknya yang menyebabkan terjadinya perubahan perubahan dalam kehidupan manusia tersebut. Dan (4) Kehidupan manusia selalu terikat dengan masa lampau karena walaupun hasil tindakan dalam menjawab tantangan bersifat final tetapi hasil dari tindakan tersebut selalu memiliki pengaruh yang tidak berhenti hanya untuk masanya tetapi berpengaruh terhadap masyarakat tadi dalam menjalankan kehidupan barunya, dan oleh karena peristiwa sejarah menjadi "bank of examples" untuk digunakan dan di sesuaikan sebagai tindakan dalam menghadapi tantangan kehidupan masa kini. Apabila keempat poin di atas dapat terlaksana dengan baik maka terlaksanalah tujuan dari pendidikan sejarah itu.

\subsection{Tujuan Mempelajari Sejarah}

Mempelajari sejarah tidak semata mata seperti mempelajari cerita rakyat yang penuh dengan mitos dan legenda yang sengaja dibuat untuk tujuan tertentu. Mempelajari sejarah sangatlah penting untuk menjawab rasa ingin tahu manusia. Tujuan sejarah itu semakin jelas, dijelaskan Rustam, (2002:5), (1) untuk memenuhi rasa ingin tahu mengenai peristiwa peristiwa masa lampau, tentang bagaimana deskripsi peristiwanya, mengapa peristiwa itu terjadi dan bagaimana akhir peristiwa itu, serta perkiraan implementasi atau dampak peristiwa tersebut terhadap bidang bidang kehidupan lainnya. (2) untuk mengetahui lebih mendalam apakah sejarah itu suatu seni atau suatu disiplin ilmu.

Apabila dalam dunia pendidikan, para siswa diarahkan oleh guru untuk mengembangkan pemikiran seperti tujuan sejarah itu, maka siswa pastinya akan menjadi kritis dalam setiap peristiwa peristiwa sejarah nasional Indonesia maupun sejarah lainnya, dan akan timbul rasa ingin tahu yang besar, dari rasa ingin tahu itu siswa akan semakin kreatif untuk menggali informasi yang mendalam dari berbagai sumber untuk mencari kebenaran dari peristiwa yang diamatinya. Dan dari situlah siswa akan menyadari bahwa ilmu sejarah itu penting untuk dipelajari.

\subsection{Manfaat Mempelajari Sejarah}

Sejarah selalu dikaitkan dengan pernyataan peristiwa atau kejadian masa lalu. Dalam cerita sejarah sumbernya adalah kejadian pada masa silam berdasarkan peninggalan sejarah. Peninggalan itu berupa hasil perbuatan manusia sebagai makhluk sosial. Menurut Rustam, (2002 : 7) manfaat mempelajari sejarah adalah kita akan dapat lebih berhati- hati agar kegagalan itu tidak terulang kembali. Tepatlah kata confutse, seorang filsuf China berkata "sejarah mendidik kita supaya bersikap bijaksana ". 
Manfaat lain dari ilmu sejarah adalah memperluas wawasan berpikir kita. Artinya sejarah secara terbuka terus memberikan pedoman dan perspektif tentang perkembangan selanjutnya, hal ini sesuai dengan pandangan yang dikemukakan Dr. Douwes Dekker (Rustam;8) memandang bahwa : Hendaknya tugas setiap ahli sejarah jangan hanya terkungkung pada zaman masa lampau saja. Melainkan menarik terus garis zaman lampau itu sejauh mungkin kemasa depan. Dari sedikit banyak fakta fakta sejarah yang tampaknya simpang siur itu, ahli sejarah harus pandai menemukan garis besarnya, dan menarik terus garis besarnya melalui masa sekarang ke masa depan. Bukan hanya tugas ahli sejarah saja, guru guru sejarah dalam proses belajar mengajar juga harus menerapkan hal seperti dipaparkan di atas, yakni dapat mengetahui garis besar dari materi sejarah yang akan di ajarkan kepada peserta didiknya. Agar pengalaman masa lampau itu dapat dijadikan pengajaran di masa yang akan datang.

\subsection{Karakteristik Pembelajaran Sejarah}

Mata pelajaran sejarah sama halnya dengan mata pelajaran lainnya dalam hal karakteristik, menurut Leo Agung dan Sri Wahyuni, (2013:61-63), karakteristik pembelajaran sejarah adalah sebagai berikut:

1) Sejarah terkait dengan masa lampau. Masa lampau berisi peristiwa dan peristiwa sejarah hanya terjadi satu kali. Jadi, pembelajaran sejarah adalah pembelajaran peristiwa sejarah dan perkembangan masyarakat yang telah terjadi. Sementara itu, materi pokok pembelajaran adalah produk masa kini berdasarkan sumber-sumber sejarah yang ada. Karena itu, pembelajaran sejarah harus lebih cermat, kritis, berdasarkan sumber-sumber, dan tidak memihak menurut kehendak sendiri dan kehendak pihak-pihak tertentu.

2) Sejarah bersifat kronologis. Oleh karena itu, pengorganisasian materi pokok pembelajaran sejarah haruslah didasarkan pada urutan kronologi peristiwa sejarah.

3) Dalam sejarah ada tiga unsur penting, yakni manusia, ruang, dan waktu. Dengan demikian, dalam mengembangkan pembelajaran sejarah harus selalu diingat siapa pelaku peristiwa sejarah, di mana dan kapan.

4) Perspektif waktu merupakan dimensi yang sangat penting dalam sejarah. Sekalipun sejarah itu erat kaitannya dengan masa lampau, waktu lampau itu terus berkesinambungan sehingga perspektif waktu dalam sejarah antara lain masa lampau, masa kini, dan masa yang akan datang. Pemahaman ini penting bagi guru sehingga dalam mendesain materi pokok pembelajaran sejarah dapat dikaitkan dengan persoalan masa kini dan depan.

5) Sejarah adalah prinsip sebab - akibat. Hal ini perlu dipahami oleh setiap guru sejarah, bahwa dalam merangkai fakta yang satu dengan yang lain, dalam menjelaskan peristiwa sejarah yang satu dengan yang lain perlu mengingat prinsip sebab - akibat. Peristiwa yang satu disebabkan oleh peristiwa yang lain dan peristiwa sejarah yang satu akan menyebabkan peristiwa sejarah yang berikutnya.

6) Sejarah pada hakikatnya adalah suatu peristiwa sejarah dan perkembangan masyarakat yang menyangkut berbagai aspek kehidupan seperti politik, ekonomi, sosial, budaya, agama, keyakinan, dan oleh karena itu, memahami sejarah dengan pendekatan multidimensial sehingga dalam pengembangan materi pokok dan uraian materi pokok untuk setiap topik haruslah dilihat dari berbagai aspek.

\section{Pendidikan Sejarah Sebagai Penguat Pendidikan Karakter}

Proses pendidikan karakter menurut Muhaimin (1996:153) dapat diaplikasikan pada pelajaran sejarah yaitu melalui beberapa tahap, yaitu:

1) Tahap transformasi nilai, merupakan suatu proses yang dilakukan oleh pendidik dalam menginformasikan nilai-nilai pendidikan karakter. Pada tahap ini hanya terjadi komunikasi verbal antara pendidik dan peserta didik;

2) Tahap transaksi nilai, merupakan tahapan untuk menyajikan pendidikan karakter melalui komunikasi dua arah atau interaksi antara peserta didik dengan pendidik yang bersifat timbal balik;

3) Tahap transinternalisasi, merupakan tahapan dimana penerapan pendidikan karakter dilakukan tidak hanya melalui komunikasi verbal, melainkan juga dengan sikap mental dan 
kepribadian ke dalam diri peserta didik. Pada tahapan ini, komunikasi kepribadian yang dijalankan pendidik kepada peserta didik lebih dominan dan berperan secara aktif.

Materi yang termuat dalam mata pelajaran sejarah memiliki ciri khas yang kuat untuk memperkenalkan bagaimana sejarah perjuangan bangsa dan aspirasi generasi terdahulu dalam upaya mewujudkan cita cita bersama sebagai negara yang berdaulat, nilai nilai yang terkandung dari peristiwa penting bangsa inilah yang akan menumbuhkan karakter seperti cinta tanah air dan semangat kebangsaan yang akan melahirkan rasa bangga menjadi bagian dari bangsa ini.

Penjabaran di atas juga diperkuat oleh pendapat Kasmadi (1996:13) yang menjelaskan tentang tujuan pembelajaran sejarah adalah untuk menanamkan semangat kebangsaan, cinta tanah air, bangsa dan negara. Menumbuhkan karakter peserta didik agar sesuai dengan tujuan pendidikan nasional tentu tidak semudah yang di bayngkan, harus di barengi dengan kebiasaan kebiasaan positif yang dilakukan secara berkesinambungan dalam lingkungan kelas seperti membuka pembelajaran dengan di sisipkan lagu lagu kebangsaan, kemudian memperkenalkan tokoh tokoh bangsa indonesia yang turut serta berjuang untuk bangsa ini, mempelajari biografi pahlawan, serta mengarahkan peserta didik akan pentingnya menghargai waktu, selanjutnya mengimpelemtasikan dalam kebiasaan sehari hari dengan tidak terlambat kesekolah, ini adalah sebagian upaya yang dapat dilakukan secara berkesinambungan untuk melakukan kebiasaan yang positif dalam lingkungan nyata.

Materi pelajaran sejarah memberikan informasi bukan hanya kesuksesan pelaku sejarah pada masa lalu namun kegagalan yang pernah dialamipun tidak luput dari sorotan sejarah, maka hal itu tentu akan memberikan pengajaran kepada masa kini tentang bagaimana harus bersikap dan cara apa yang harus dilakukan apabila peristiwa yang serupa di alami, merujuk dari pelaku dan peristiwa sejarah terdahulu.

Pendidikan sejarah sebagai penguat pendidikan karakter juga dapat dilihat dari pendapat para pakar seperti yang di kemukakan oleh Sapriya (2012:209) Pendidikan sejarah memiliki cakupan materi sebagai berikut: (1) mengandung nilai-nilai kepahlawanan, keteladanan, kepeloporan, patriotisme, nasionalisme, dan semangat pantang menyerah yang mendasari proses pembentukan watak dan kepribadian peserta didik; (2) memuat khasanah mengenai peradaban bangsa-bangsa termasuk peradaban bangsa Indonesia; (3) menanamkan kesadaran persatuan dan persaudaraan serta solidaritas untuk menjadi pemersatu bangsa dalam menghadapi ancaman disintegrasi; (4) memuat ajaran moral dan kearifan yang berguna dalam mengatasi krisis multidimensi yang dihadapi dalam kehidupan sehari-hari; (5) menanamkan dan mengembangkan sikap bertanggung jawab dalam memelihara keseimbangan dan kelestarian lingkungan hidup.

Pendapat di atas menegaskan bahwa pendidikan sejarah memang memiliki andil yang besar dalam membentuk kepribadian serta watak yang sejalan dengan tujuan pendidikan nasional. Peran penting pembelajaran sejarah bukan hanya sebagai proses transfer ide, akan tetapi juga proses pendewasaan peserta didik untuk memahami identitas, jati diri dan kepribadian bangsa melalui pemahaman terhadap peristiwa sejarah. Menurut Kochhar (2008:27-37) tujuan pembelajaran sejarah adalah sebagai berikut:

1) Mengembangkan pemahaman tentang diri sendiri;

2) Memberikan gambaran yang tepat tentang konsep waktu, ruang dan masyarakat;

3) Membuat Peserta Didik Mampu Mengevaluasi Nilai Dan Hasil Yang Dicapai Generasinya

4) Mengajarkan toleransi;

5) Memperluas cakrawala intelektualitas;

6) Mengajarakan prinsip-prinsip moral;

7) Menanamkan orientasi ke masa depan;

8) Melatih peserta didik menangani isu-isu kontroversial;

9) Membantu memberikan jalan keluar bagi berbagai masalah sosial dan perorangan;

10) Memperkokoh rasa nasionalisme;

11) Mengembangkan pemahaman internasional;

12) Mengembangkan keterampilan-keterampilan yang berguna. 


\section{Simpulan dan saran}

Berdasarkan uraian di atas maka dapat disimpulkan sebagai berikut. Pertama, pendidikan sejarah sebagai pendidikan yang mempelajari peristiwa masa lalu merupakan sarana transmisi nilai karakter dari generasi sebelumnya ke generasi berikutnya Kedua, menumbuhkan karakter melalui pendidikan sejarah bukanlah sekedar menghafal dan mengetahui peristiwa tersebut, melainkan mengembangkan dan mengimplementasikan dalam kehidupan sehari hari. Mampu merubah cerita sejarah yang tidak terkait dengan masa kini, menjadi pengajaran yang yang kaya akan nilai nilai yang dapat di terapkan dalam kehidupan saat ini. Ketiga, penanaman dan penerapan nilai-nilai kepahlawanan para pejuang bangsa indonesia sangat penting dan diperlukan dalam membentuk keperibadian generasi bangsa yang berkarakter dan bermoral serta memiliki semangat kebangsaan, dan cinta tanah air, merasa bangga menjadi bagian dari bangsa indonesia.

\section{Daftar Rujukan}

Elmubarok Zaim. 2009. Membumikan Pendidikan Nilai. Bandung: Alfabeta

Fatthurrohman, P., Suryana., Fatriani, F. 2013. Pengembangan Pendidikan Karakter. Bandung: PT Refika Aditama.

Harsojo, A. 2013. Membangun Karakter Berkearifan Lokal dalam Bingkai Pendidikan Persekolahan. Jurnal Pelopor Pendidikan. 4 (1). 19-28.

Leo Agung, Sri Wahyuni. 2013. Perencanaan Pembelajaran Sejarah. Yogyakarta: Ombak Dua.

Muhaimin. 1996. Strategi Belajar Mengajar. Surabaya: Citra Media.

Kochhar, S. K. 2008. Pembelajaran Sejarah (Teaching of History). Jakarta: PT Gramedia Widiasarana Indonesia.

Samani, Muchlas dan Hariyanto. 2011. Konsep dan Model Pendidikan Karakter. Bandung: Remaja Rosdakarya.

Sapriya. 2009. Pendidikan IPS Konsep dan Pembelajaran. Bandung: PT Remaja Rosdakarya.

Kasmadi, Hartono. 1996. Model-model dalam Pengajaran Sejarah. Semarang: IKIP Semarang Press.

Susanto Heri. 2014. Seputar Pembelajaran Sejarah, Isu, Gagasan Dan Strategi Pembelajaran. Yogyakarta Aswaja Presindo

Rusman. 2012. Model- Model Pembelajaran, Jakarta PT RajaGrafindo Persada

Trianto, 2008. Mendesain Pembelajaran Kontekstual, Jakarta : Cerdas Pustaka

Widja, I Gde. 2007. Dasar-dasar Pengembangan Strategi Serta Metode Pengajaran Sejarah. Jakarta: P2LPTK 